\title{
Lorne Peak Station - achieving sustainable profitability in challenging Southland hill country
}

\author{
M. TAYLER ${ }^{1}$, L. DONNELLY ${ }^{2}$, P. FRATER ${ }^{3}$ and N. STOCKER ${ }^{2}$ \\ ${ }^{1}$ Lorne Peak Station, Kingston Garston Highway, RD 3, Lumsden, Southland 9793, New Zealand \\ ${ }^{2}$ Seed Force Ltd, PO Box 16 625, Christchurch 8042, New Zealand \\ ${ }^{3}$ FARMAX ${ }^{\circledR}$, Waikato Innovation Park, Ruakura Lane, PO Box 1036, Hamilton 3240, New Zealand
}

liamdonnelly@seedforce.co.nz

\begin{abstract}
Lorne Peak Station, near Garston in Northern Southland is a 5650 ha station, which until recently, has been run as an extensive store sheep and beef property. Major constraints for this hill country property, like many others in the region, are long winters with occasional snowfall, low pasture growth rates, dry summers, unpredictable autumns and limited cash flow to develop and improve the land. The intensification of New Zealand's hill country farms is a critical aspect in ensuring financial viability. Since 2009, Lorne Peak has undergone a rigorous intensification program, initially aided by income produced from wintering dairy cows on the property. With careful selection of crops and pastures, farm profitability has increased, through selection of different stock breeds/classes and high utilisation of feed supply over the year. FARMAX ${ }^{\mathbb{R}}$ modelling software has been used retrospectively to analyse these changes, and compare it with the current scenario. The analysis clearly shows that the use of lucerne for grazing, fodder beet for beef production, subdivision and increasing soil fertility have been real game changers for Lorne Peak. A 292\% increase in farm profit before tax is testament to this achievement. However, an increase of $26 \%$ for total farm working expenses, highlights the need for investment to be planned to build resilience into the farming operation.
\end{abstract}

Keywords: hill country, intensification, dryland, lucerne, fodder beet, sheep, beef, FARMAX ${ }^{\circledR}$, profitability

\section{Key messages}

- Intensive land development in Northern Southland hill country has allowed for diversification of both pasture and crop species resulting in greater pasture persistency, higher yields, as well as matching feed supply to increasing demand

- The inclusion of both lucerne and fodder beet in the farming system have assisted with finishing more sheep and beef stock on the property, with notable increases in lambing percentages and liveweight gains

- The development of the property and subsequent changes to the farming system have resulted in an increase in farm profit of $292 \%$ (before tax) between the years 2009 and 2014, illustrating the potential benefits for similar hill country properties, should they look to intensify their farming system.

\section{Introduction}

Lorne Peak Station is an example of an extensive hill country sheep and beef farming operation that has needed to intensify its system to remain profitable in the $21^{\text {st }}$ century. The property has a diverse range of topography, soil types and climatic conditions, similar to many other hill country farms around New Zealand. Major drivers for intensification were farm succession, potential tenure review, increasing costs (operating, regulatory and compliance), steeply rising land values and the removal of price support for agricultural products during the general deregulation of the New Zealand economy in the late 1980s (MacLeod \& Moller 2006).

The introduction of wintering dairy cows on the flat to rolling areas of the property in the mid-2000's has provided enough cash flow to enable considerable development of the tussock flats and lower hill country through scrub removal, subdivision, improving fertility, and pasture renovation, over the past 15 years. However, it has been in the last 5 years that the real benefit of this development has become evident through increased productivity and profitability. This has created new goals for Lorne Peak, with more emphasis being put on producing an increased volume of higher value product off every hectare farmed. Much of this can be attributed to a strong emphasis on species diversity in pastures and crops, such as lucerne being grown on newly developed land.

With the use of FARMAX ${ }^{\circledR}$ modelling software, Lorne Peak has been able to monitor productivity gains of pasture, crops and stock, retrospectively, as well as modelling potential scenarios for the future. The overall long-term objective for the property is to remove the requirement to winter high numbers of dairy cows to supplement farm income, and create a robust farm system where complementary livestock species and classes are well matched to the pasture/ 
crop growth curve in the hill country environment. The farm staff take pride in stockmanship, and wish to reap the benefits of adding value to Station stock rather than other temporarily grazed stock.

\section{Modelling with FARMAX Pro}

FARMAX Pro, a software program developed by FARMAX $^{\circledR}$, has allowed Lorne Peak to carry out monitoring and analysis of its farm system as well as a range of scenarios for the same physical location. FARMAX Pro is based off an earlier agricultural modelling program called MAF Stockpol (Marshall et al. 1991). The key function of FARMAX Pro is to determine if the planned stocking policy is biologically feasible (White et al. 2010) and thus has been hugely beneficial for determining what forage should be planted, as well as what stock classes and numbers can be run and/or finished on farm.

Once crop yields, pasture covers and growth rates have been entered into the program, a range of scenarios can be created and the viability of each calculated. Where feed supply/demand is calculated as either grossly short or excessively above requirements the program will prompt an 'infeasible' notification. Scenarios can be further altered by changing both management decisions (i.e. applying fertiliser, lambing earlier, or buying in supplements) and their timings within the year, before comparing with the current farming system.

Metabolisable energy (ME) values for the pasture components are also defined within the model. All sources of feed are entered into the model and can be modified by the user. For stock, ME requirements are based on equations (Parks 1982), using animal weight, age, sex and stage of pregnancy to calculate total feed requirements. FARMAX Pro calculates the potential intake for each animal, without allowing it to be exceeded and thus the model remains realistic.

For the purpose of this paper, all aspects of the farming operation in 2009 have been retrospectively entered into FARMAX Pro and compared with the developed property in 2015. This comparison highlights the extent to which land development, subdivision and subsequent improved crops/pastures have influenced the overall profitability of the farming operation.

\section{Lorne Peak Station \\ History}

Lorne Peak Station consists of 5400 ha of pastoral lease, with a further 250 ha freehold. When the property was purchased by George Tayler in 1960, it ran 3000 hungry ewes, a handful of cattle and a horse. In 1972, George purchased the neighbouring Kingston Station but died soon after, leaving his son Phillip to farm in partnership with his brother, Ken. They added two further freehold farms before Ken died, and subsequently the partnership and landholding was split around 8 years ago. Phillip continued the trend of giving the next generation a turn at farming the land, by handing control over his son, Matthew. Phillip still plays an active role on the farm, however, he has largely swapped dogs for a tractor, and has been heavily involved with the development phase undertaken by the property over the last 15 years.

\section{Development of land with varying topography, soil types and fertility}

Altitude ranges from 310 to $1500 \mathrm{~m}$ a.s.l. In total, 1200 ha of flat to rolling country is cultivatable, with average to good fertility (pH 6.0., Olsen P 18+) following an intensive capital fertiliser/lime program over the past 10 years. Sulphur and potassium levels are also being addressed. There is a potential to cultivate and develop a further 200-300 ha, however, there are constraints imposed due to biodiversity/landscape concerns by Land Information New Zealand and the Department of Conservation.

Soil types in this area of northern Southland vary widely, but the flats are predominantly shallow, stony fluvio-glacial, free draining through to deep loess on the terraces and river silts on some flats. Previously considered a weakness, the stone-free draining soils are now an advantage with the addition of 250 hectares of lucerne to the system for grazing over the last 3 years. These lucerne stands provide both a top quality finishing block and a source for much of the supplementary feed required by the property.

There are 400 ha of oversown, top-dressed (OSTD) tussock flats that is too rocky to cultivate. This country is very safe lambing country. Over the past 5 years, $\mathrm{pH}$ has been raised from 4.9 to 5.5 , phosphorous levels from 8-10 to 15 , while addressing sulphur along with oversowing red and white clover plus cocksfoot, increasing stock units $\mathrm{(su}$ ) from $<1$ to $3-4$ /ha. Aluminium toxicity was an issue before liming. This development has only been possible as a result of the cash injection provided from wintering dairy cows.

Another 1000 ha of OSTD hill are in varying states of improvement. Base fertility consists of a $\mathrm{pH}$ of 5.5, Olsen $\mathrm{P}<15$, as well as low sulphur levels, providing an opportunity for future improvement to these areas, along with subdivision, scrub spraying and pasture renovation. Brassicas including forage rape and turnips will be sown using a spray and oversow technique, followed by planting permanent pastures containing a mixture of plantain, red and white clovers.

The balance of the land area at Lorne Peak Station includes bush and summer country ( $>850 \mathrm{~m}$ a.s.1.), and a potential development opportunity for the future of another 500 ha of unimproved, predominately cold hill country with an altitude of $<850 \mathrm{~m}$. The establishment of lucerne on the flats has raised concern about possibly 
running out of suitable country for ewes. However, the future options likely include lambing later in November on these colder hill areas, and utilising the lucerne to finish these lambs before winter. The OSTD hill also can be utilised for this purpose.

The development program to date has been successful. The next phase is to extract more production from the OSTD hill blocks, as well as bringing in the undeveloped hill. In the last 8 years, in excess of $12 \mathrm{~km}$ of new fencing has been erected annually, as well as $\$ 10-\$ 25 /$ su spent on fertiliser. Pasture renovation has been a big focus, with the better feeding of capital stock the main driver in lifting animal performance.

\section{Stock}

Lorne Peak Station has traditionally focused on breeding stock and selling store lambs and calves as the main source of income. However, changes to its pastoral system over the last five years allows the property to finish more lambs on the lucerne paddocks. Ewes rotationally graze lucerne paddocks until weaning which results in higher weaning weights. Lucerne also provides the opportunity to finish lambs born on the hill blocks on a high quality crop.

In the 2014/15 season, 10000 Romney ewes were wintered along with 900 half-bred ewes and 3000 Romney hoggets. Lorne Peak has made a shift away from a half-bred flock, to Romneys, as it is a better fit for the pastoral growth curve since the development. A single breed has led to fewer mobs, making it easier to plan the winter rotation, easier on pastures, and more sorting of ewes on condition rather than breed. Romneys have been found to be more suitable to mob-stocking through winter, leading to better control of pasture quality, controlling scrub and allowing paddocks to be locked up for early spring growth.

The ratio of lambs weaned to ewes mated at docking in the 2014/15 season was $133 \%$ (14 600 lambs from 10 900 ewes mated).This is a large increase on the 2013/14 season where ewes weaned $118 \%$ of lambs, as well as in previous seasons where percentages ranged from 100 to $110 \%$. This is a notable achievement for the property, particularly as mixed-aged ewes graze above $850 \mathrm{~m}$ on native/snow tussock country between January and March, and these data include the half-bred ewes run by the property. Lorne Peak Station is striving to reach a target lambing percentage of $140 \%$ in the future.

In addition to the sheep enterprise, there are 320 rising 3-year old and mixed-age cows and 75 in-calf heifers producing 340 home-bred calves, as well as 90 empty/unmated rising 2-year old (R2) heifers, and 160 R2 steers. Depending on the feed supply, 100-200 weaner calves or R2 cattle are bought annually.

Lastly, 1150 dairy cows are wintered for 10 weeks from $1^{\text {st }}$ June (has been up to 2500).

\section{Crops, pastures and their management}

Pasture improvement and species diversity has been a big focus for the property - a direct result of developing more land. However, the types and locations of crops and pastures grown on Lorne Peak are still largely determined by the varying soil types, contours and climates. Swedes, kale, fodder beet, whole crop triticale and tetraploid ryegrass varieties are grown in well-developed paddocks with adequate fertility. The majority of the brassica crops are used for wintering dairy cows, with fodder beet and the remainder of the kale providing feed for sheep and beef stock units.

Traditional long-rotation and perennial ryegrass pastures have become more diversified, now including a wider range of pasture species including cocksfoot and timothy, along with red clover, chicory and plantain. These mixed-species swards add versatility to the ryegrass- based pasture system, while also providing a high quality feed for tupping and finishing stock. Red clover has proven useful in combating dry summer conditions in combination with cocksfoot, in the battle with porina and grass grub pasture pests on the heavy loess terraces.

In addition to pastures with increased species diversity, the incorporation of lucerne and fodder beet into the existing perennial ryegrass/brassica system has also made a major contribution to feed supply and subsequent financial return. On light ground at Lorne Peak the most common crop rotation is turnips to kale, then lucerne.

Lucerne has proven to be a particularly good fit for sheep and beef finishing at Lorne Peak, as it is well suited to the environment, with long taproots accessing soil moisture at greater soil depths (Mills et al. 2008) and tolerance of insect pests. On average, the lucerne stands produce approximately 2.5 times the yield of a 2-3 year old perennial pasture on the same ground, with the added benefit of providing a higher quality feed at around 11 MJME/kg DM (Mills \& Moot 2010). Lorne Peak has calculated a return on investment for lucerne stands planted over the past 4 years to be $22 \%$.

The addition of lucerne has given more certainty around availability of quality feed for both hoggets and ewes/lambs in spring. Hoggets grazing lucerne in early spring had an average liveweight gain of 200 $\mathrm{g} /$ day between September and November. Ewes and lambs following the hoggets on the lucerne, achieved an average liveweight gain of 280-300 g/day. Lambs grazed post-weaning averaged between 200-250 g/ day. Lambing percentage has increased $33 \%$ in the past five seasons, a direct result of changing sheep breeds to better fit the new growth curve, and emphasis on growing lambs quickly.

Beef cattle have also benefited from increased areas of lucerne planted, in combination with long rotation 


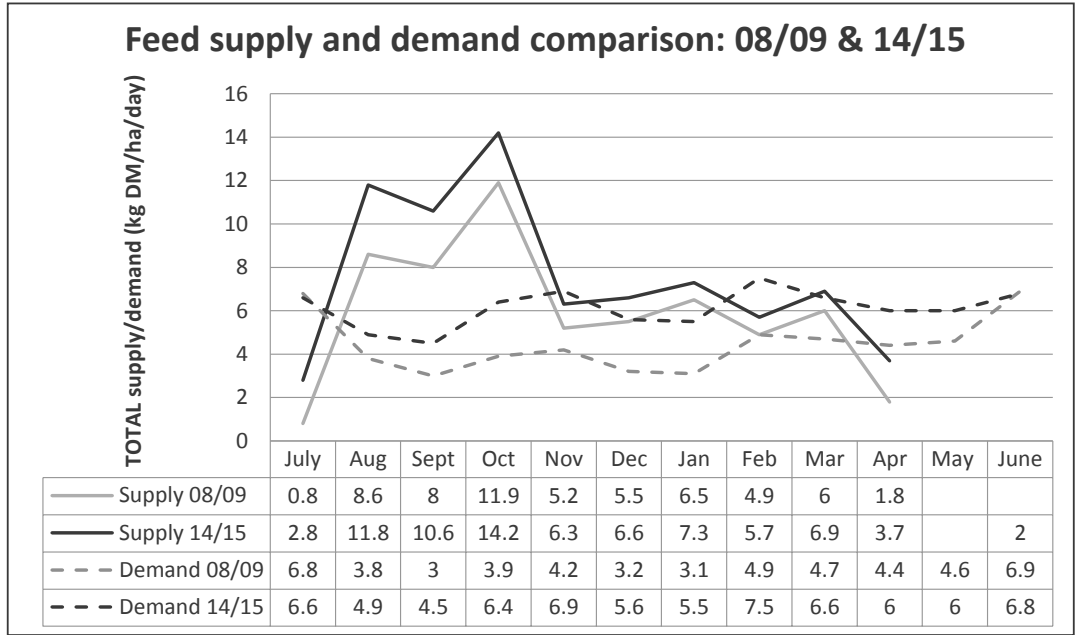

Figure 1 Comparison of supply and demand between undeveloped (base) model for Lorne Peak in 2008/09 and developed in 2014/2015.

ryegrasses and fodder beet resulting in exceptional liveweight gains. Lorne Peak now finishes its rising 2-year old (R2) cattle instead of selling store at 20 months. The fodder beet also allows an extra 30 heifers weighing in excess of $320 \mathrm{~kg}$ to be mated, after yearlings are wintered on fodder beet.

While winter forage crops including swedes, turnips and kale are incorporated into the crop rotation as less productive land is transformed and prepared for permanent pasture or lucerne stands. Fodder beet has added to the flexibility of the system in more recent times, particularly due to the larger seasonal window in which the crop can be utilised, along with impressive liveweight gains in stock grazing the crop over the winter. Fodder beet has resulted in R1 cattle achieving liveweight gains of 600-650 g/day and 900-1000 g/day in R2 stock.

\section{Evaluating progress using FARMAX Pro Matching feed supply/demand to stock classes}

Farmax Pro has highlighted the positive contribution of adding both lucerne and fodder beet into the farming system in recent years, with increased feed supply well matched to increase stock demand in the 2014/15 year (Figure 1).

As a result, the property is looking to replace more of the kale area with fodder beet in the future, where soil type and contour allow. While the beet crops at first appear to be more expensive to grow than kale (approximately $\$ 2200$ versus $\$ 1000 /$ ha), the higher yield (average of 23 versus 15 tonnes DM/ha) and better utilisation (approximately $90 \%$ versus 65\%) result in a similar or even slightly lower cost per kilogram of dry matter utilised, with added bonus of better quality feed providing more options for stock finishing.

The fodder beet grazing system used for beef stock is based on the 'Fisher Model' developed by Lincoln University's Dr Jim Gibbs (Gibbs \& Saldias 2014) allowing Lorne Peak to finish the majority of the steers and heifers, rather than selling as store at 20 months old. Again, this is a huge positive in terms of matching the feed the beet provides in the winter, and shifting the animals on at a time when premiums exist.

FARMAX Pro has allowed the property to model various crop and stocking scenarios, assisting with decision making and has helped with its planned transition from wintering dairy cows for 10 weeks between June and August, back to finishing their own beef stock, and utilising additional fertility following fodder beet crops with whole crop cereal silage.

Feeding fodder beet during winter is leading to heavier heifers at mating, looking at once- bred heifer system. Another positive effect of wintering yearlings on beet is they don't need to preferentially feed the steers through spring/summer/autumn to hit Lorne Peaks' minimum target of $440 \mathrm{~kg}$ in May before they go on the fodder beet. The steers come out of the first winter at $340 \mathrm{~kg}$ minimum, meaning they only need to achieve $500 \mathrm{~g}$ /day over spring/summer, and ewes and lambs or mated heifers get preference for spring grazing.

\section{Finanial benefits}

The management decisions put in place to move to a different pastoral base on the flats (lucerne) the use of fodder beet (increased yields/quality and stock performance) coupled with subdivision and increasing fertility levels has created a profitable return for Lorne Peak Station. Although the intensive development program has resulted in increased total farm working expenses $(26 \%)$, the overall profitability has jumped $110 \%$.

Modelling with FARMAX Pro has calculated an extra \$103/ha gross margin based on these changes (Table 1). The cash injection from the dairy grazing has been instrumental in kick-starting this development. However, as with Bog Roy Station (Anderson et al. 2014) and Greenfields (Kearney et al. 2010), who have implemented lucerne systems in recent years, the crop has been shown to reap a high rate of return for the investment made, through higher stocking rates and 
Table 1 Revenue and expenditure report: comparison between 2009 and 2015 at Lorne Peak Station.

\begin{tabular}{|c|c|c|c|c|c|c|}
\hline & & & $\begin{array}{r}2009 \\
\text { (Base year) }\end{array}$ & 2015 & $\begin{array}{r}\text { Monetary } \\
\text { Difference }\end{array}$ & $\%$ Change \\
\hline \multirow[t]{9}{*}{ Revenue } & \multirow[t]{3}{*}{ Sheep } & Sales - Purchases & 444184 & 987518 & 543334 & 122 \\
\hline & & Wool & 139505 & 230243 & 90738 & 65 \\
\hline & & Total Sheep & 583689 & 1217761 & 634071 & 109 \\
\hline & \multirow[t]{3}{*}{ Beef } & Sales - Purchases & 81293 & 303125 & 221832 & 273 \\
\hline & & Contract Grazing & 552434 & 383865 & -168569 & -31 \\
\hline & & Total Beef & 633727 & 686990 & 53263 & 8 \\
\hline & \multirow[t]{2}{*}{ Crop \& Feed } & Capital Value Change & -85800 & -40800 & 45000 & -52 \\
\hline & & Total Feed & -85800 & -40800 & 45000 & -52 \\
\hline & \multicolumn{2}{|l|}{ Total Revenue } & 1131617 & 1863951 & 732334 & 65 \\
\hline \multirow[t]{24}{*}{ Expenses } & \multirow[t]{4}{*}{ Feed/Crop/Grazing } & Conservation & 100880 & 112920 & 12040 & 12 \\
\hline & & Forage Crops & 301500 & 369000 & 67500 & 22 \\
\hline & & Regrassing & 28200 & 44400 & 16200 & 57 \\
\hline & & Total Crop \& Feed & 430580 & 526320 & 95740 & 22 \\
\hline & \multirow[t]{3}{*}{ Stock } & Animal Health & 47816 & 63126 & 15309 & 32 \\
\hline & & Shearing & 40683 & 58667 & 17984 & 44 \\
\hline & & Total Stock Costs & 88499 & 121793 & 33293 & 38 \\
\hline & \multirow[t]{3}{*}{ Wages } & Wages & 92616 & 134817 & 42201 & 46 \\
\hline & & Management Wages & 5296 & 7710 & 2413 & 46 \\
\hline & & Total Wages & 97912 & 142527 & 44614 & 46 \\
\hline & \multirow[t]{4}{*}{ Fertiliser } & Fertiliser (Excl. N \& Lime) & 50004 & 50004 & 0 & 0 \\
\hline & & Nitrogen & 5136 & 17441 & 12305 & 240 \\
\hline & & Lime & 7452 & 7452 & 0 & 0 \\
\hline & & Total Fertiliser & 62592 & 74897 & 12305 & 20 \\
\hline & \multirow[t]{8}{*}{ Other Farm Working } & Irrigation Charges & 3618 & 3618 & 0 & 0 \\
\hline & & Weed \& Pest Control & 18846 & 18846 & 0 & 0 \\
\hline & & Vehicle Expenses & 14904 & 14904 & 0 & 0 \\
\hline & & Fuel & 15876 & 15876 & 0 & 0 \\
\hline & & Repairs \& Maintenance & 56686 & 82516 & 25830 & 46 \\
\hline & & Freight \& Cartage & 14028 & 20421 & 6392 & 46 \\
\hline & & Electricity & 10020 & 14586 & 4566 & 46 \\
\hline & & Total Other Farm Working & 133978 & 170767 & 36788 & 27 \\
\hline & \multirow[t]{2}{*}{ Standing Charges } & Admin, Insurance, ACC, Rates & 15120 & 15120 & 0 & 0 \\
\hline & & Total Standing Charges & 15120 & 15120 & 0 & 0 \\
\hline \multicolumn{3}{|c|}{ Economic Farm Surplus (EFS) } & 237702 & 747295 & 509593 & 214 \\
\hline \multicolumn{3}{|c|}{ Gross Margin } & 508557 & 1064597 & 556040 & 109 \\
\hline \multicolumn{3}{|c|}{ Gross Margin/ha } & 94 & 197 & 103 & 110 \\
\hline \multicolumn{3}{|c|}{ Farm Profit before tax } & 174522 & 684115 & 509593 & 292 \\
\hline \multicolumn{3}{|c|}{ Farm Profit/ha before tax } & 32 & 127 & 94 & 294 \\
\hline
\end{tabular}

*Figures that remain unchanged between 2009 \& 2015, have been taken from the Beef \& Lamb 2014/15 National Survey Data (Beef \& Lamb 2015). 
less variance between feed supply and demand.

Changing the stock classes at Lorne Peak has resulted in a reduced income from wintering dairy stock (by \$168 569 comparing 2015 with 2009), however, sheep sales increasing by $122 \%$ and beef by $273 \%$ have offset the $30 \%$ decline in dairy grazing income. Wool sales have also increased by another $\$ 90738$ over this period. Before the property development began in 2009, the annual farm profit before tax was calculated to be $\$ 32 /$ ha. Six years later, the same property boasts a $294 \%$ increase in farm profit before tax, equal to $\$ 127 / \mathrm{ha}$.

Finishing cattle to heavier weights at 22 months on fodder beet and getting a premium for winter supply is better suited to feed supply on the property, and is more beneficial from a financial point of view. This saves preferentially feeding cattle through summer/autumn to kill light at 18 months on a poor schedule and at the expense of the ewe/lamb system. With beef cattle sold earlier, there is increased land area available to ewes with lambs at foot, providing better quality feed, and reduced stocking rates for other stock classes. Lambs are weaned at higher weights, with many finished on farm and ewes remain in better body condition.

It is important to note that major changes in farm systems are not reflected in FARMAX ${ }^{\circledR}$ models. The property has gone from operating with no additional staff, to employing a stock manager and tractor driver. Large variations in working capital are a result of infrastructure (yards, lanes, houses etc.) are struggling to keep up with the changes to the property, and thus need upgrading.

\section{Refining the farming system in the future}

The lucerne grazing base that Lorne Peak has developed had some initial difficulties. There has been movement away from lambing ewes on lucerne as animal health issues and the unpredictability of spring growth have strained the system. The paddocks are rocky and only a small area is able to be conserved. The main use is now initially for growing out the hoggets in the early part of spring, followed by ewes with lambs at foot. This is providing higher lamb growth rates $(280-300 \mathrm{~g} / \mathrm{head} /$ day) than observed when grazing perennial pastures, which produce seedheads and lose feed quality.

Lack of persistency in perennial ryegrass/white clover pastures has been a driver to diversify the range of pasture species used on the property to ensure ongoing profitability. Brazendale et al (2011) modelled the effects of pasture persistency moving from 4 to 8 years, showing large impacts upon whole farm profitability. One key advantage of lucerne systems is persistency, which has been highlighted in many studies, particularly the 'MaxClover grazing experiment' undertaken over 9 years with Lincoln University (Mills et al. 2014).

\section{Conclusions}

Lorne Peak Station is an ongoing example of how hill country land can be developed and farmed in a sustainable, profitable manner. In New Zealand there is considerable opportunity to look at other pastures outside of the traditional perennial ryegrass/white clover swards, and the property has reaped the benefits of doing so. Lucerne in particular has been a good fit for newly developed land on the property, where ryegrass and other species fail to persist in various climates and soil types. The grazing platform developed over recent years has been a good fit for changing stock classes from running store animals and winter grazing large numbers of dairy stock, to the more preferred option of primarily sheep and beef. Increased feed supply, and higher stocking rates as a result have been key drivers in a hill country property becoming a profitable finishing operation.

Phenomenal liveweight gains in beef animals grazing fodder beet has also been a crucial feature in finishing more stock, at a younger age and thus contributing to the $273 \%$ increase in revenue from cattle sales between 2009 and 2015. Fodder beet costs more to grow, but higher yields and better utilisation in comparison with kale, it is more economical to grown on a cents per $\mathrm{kg}$ DM grown basis.

While pasture and crop diversity, and the benefits for sheep and beef have been highlighted in this paper, it would not be possible without increased subdivision and a strong fertiliser program. Focus must be placed on these aspects of property development well before decisions around seed and stock are made. If these are the other way around, high farm expenditure limits the profitability of the system, and the development costs far more, as both crops and stock are not able to reach their true potential.

A number of the alternative pastoral and cropping options described in this paper are realistic alternatives for hill country farmers to consider. FARMAX ${ }^{\circledR}$ is a useful modelling tool to highlight the benefits of various scenarios, but there are also a growing number of farmers who have been successful in implementing similar systems on hill country properties across New Zealand. However, future success stories should not be limited to properties with steep topography - the Lorne Peak model can relate to land with flat to rolling contour, particularly where rainfall figures support the use of traditional ryegrass white clover pastures systems, yet soils have poor water holding capacity. This has long been publicised by the likes of Professor Derrick Moot at Lincoln University and extensive sheep, and beef farming operation such as Lorne Peak are proving it to be successful at a farm systems level. 


\section{REFERENCES}

Anderson, D.; Anderson. L.; Moot, D.J.; Ogle, G.I. 2014. Integrating lucerne (Medicago sativa L.) into a high country merino system. Proceedings of the New Zealand Grassland Association 76: 29-34.

Beef \& Lamb. 2015. Class 2 Southern South Island Hill Country. Accessed 1/11/15. http://www.beeflambnz. com/information/on-farm-data-and-industryproduction/sheep-beef-farm-survey/ssi/nz/

Brazendale, R.; Bryant, J.R.; Lambert, M.G.; Holmes, C.W.; Fraser, T.J. 2011. Pasture Persistence: how much is it worth? Pasture Persistence - Grassland Research and Practice Series 15: 3-6.

Gibbs, S.J.; Saldias, B. 2014. Feeding fodder beet in New Zealand beef and sheep production. pp. 83-90. In: Proceedings of the Society of Sheep and Beef Cattle Veterinarians of the New Zealand Veterinary Association.

Kearney, J.K.; Moot, D.J.; Pollock, K.M. 2010. Onfarm comparison of pasture production in relation to rainfall in Central Otago. Proceedings of the New Zealand Grassland Association 72: 121-133.

MacLeod, C.J.; Moller, H. 2006. Intensification and diversification of New Zealand agriculture since 1960: an evaluation of current indicators of land use change. Agriculture, Ecosystems and Environment 115: 201-218.

Marshall, P.R.; McCall, D.G.; Johns, K.L. 1991. Stockpol: a decision support model for livestock farms. Proceedings of the New Zealand Grassland Association 53: 137-140.

Mills, A.; Moot, D.J. 2010. Annual dry matter, metabolisable energy and nitrogen yields of six dryland pastures six and seven years after establishment. Proceedings of the New Zealand Grassland Association 72: 177-184.

Mills, A., Smith, M.C.; Lucas, R.J.; Moot, D.J. 2008. Dryland pasture yields and botanical composition over 5 years under sheep grazing in Canterbury. Proceedings of the New Zealand Grassland Association 70: 37-44.

Mills, A.; Lucas, R.J.; Moot, D.J. 2014. 'MaxClover' grazing experiment: I. Annual yields, botanical composition and growth rates of six dryland pastures over nine years. Grass and Forage Science 70: 557-570.

Parks, J.R. 1982. A Theory of Feeding and Growth of Animals. Springer-Verlag, Heidelberg. 322 pp.

White, T.A.; Snow, V.O.; King, W. McG. 2010. Intensification of New Zealand beef farming systems. Agricultural Systems 103: 21-35. 
